УДК 577.2

DOI: 10.33184/spbgb-2021-09-21.29

\title{
Роль глутатион-S-трансфераз в растениях семейства Капустных
}

\author{
( Е.В. Михайлова, М.Ю. Шеин, В.Ю. Алексеев \\ Институт биохимии и генетики УФИЦ РАН \\ Россия, Республика Башкортостан, 450075 г. Уфра, проспект Октября, 71
}

\section{Email:mikhele@list.ru}

Обсуждается возможность повышения устойчивости растений семейства капустных к мучнистой росе и другим стрессовым фракторам путем гетерологичной экспрессии генов глутатион-S-трансфераз.

Ключевые слова: рапс, Brassicaceae, Brassica napus, GST, GSH, мучнистая роса, Erysiphe cruciferarum, Erysiphe communis

К растениям семейства Капустных (Brassicaceae) относятся ценные сельскохозяйственные культуры, которые используются в качестве овощных, масличных, сидератов и фиторемедиаторов: репа, пекинская капуста, редька, брюква, множество подвидов капусты (кочанная, цветная, брокколи, кольраби и др.), горчица белая, горчица сарептская, руккола, и самая популярная культура - рапс. Рапс Brassica napus L. является гибридом репы $B$. rapa и капусты $B$. oleracea. Гибридизация играет огромное значение в эволюции и видообразовании Капустных [1].

Помимо средиземноморской рукколы, остальные культуры являются чрезвычайно устойчивыми к неблагоприятным абиотическим фракторам. Особенно отличаются они холодостойкостью, что позволяет успешно культивировать их в умеренных широтах [2]. Основную угрозу урожаям этих культур представляют насекомые-вредители и грибные заболевания. Жуки семейства листоедов (рапсовый цветоед, рапсовый листоед, крестоцветная блошка и др.), тля, капустная моль способны нанести существенный вред урожаю. Наиболее опасные заболевания, которыми рапс поражается на протяжении всего жизненного цикла, вызываются грибами четырех классов (Deuteromycetes, Zygomycetes, Oomycetes и Ascomycetes) [3]. Из этих заболеваний следует отдельно выделить мучнистую росу (Erysiphe cruciferarum), которая, в отличие от большинства остальных грибов, проявляет себя в конце лета, при чередовании влажной и засушливой погоды, и поражает широкий спектр растительных семейств: Capparidaceae, Brassicaceae, Resedaceae, Papaveraceae, Fumariaceae [4]. Сорта рапса, устойчивые к мучнистой росе, до сих пор не были получены ни путем традиционной селекции, ни методами генной инженерии [5]. Единственным на данный момент методом борьбы с ними остается обработка семян и посевов фрунгицидами.

Еще одним уникальным свойством мучнистой росы является облигатная биотрофность и, как следствие, невозможность её культивирования на питательных средах [6]. Этим объясняется то, что из множества растительных патогенов мучнистая роса - один из наименее хорошо изученных. Грибы Erysiphe не представлены ни в одной коллекции. Тем не менее, геномы соответствующих патогенов винограда, кизила, бобовых растений уже были секвенированы. Генетически Erysiphe cruciferarum с высокой достоверностью выделяется в отдельную группу, наиболее близкородственную видам грибов E. buhrii и E. betae, паразитирующих на Гвоздичных, в частности на свекле (рис. 1). 


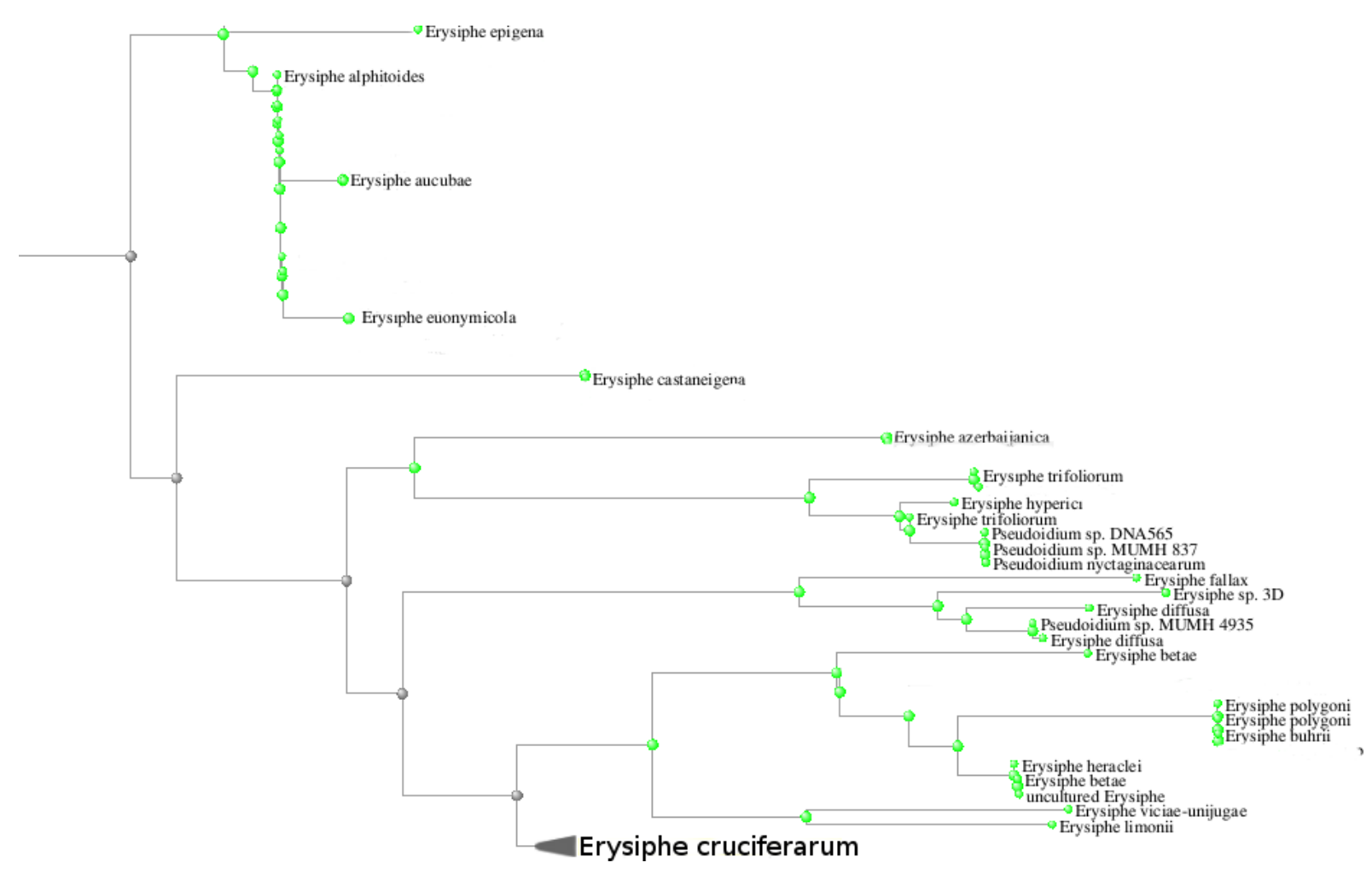

Рис. 1. Филогенетическое древо грибов рода Erysiphe, построенное с использованием BLAST pairwise alignments

Одним из важнейших соединений, задействованных в обеспечении устойчивости растений к стрессам, являются глутатион (GSH) и катализирующая реакции с его участием глутатион-S-трансфераза (GST). GST могут выполнять роль GSH-трансфераз, GSHзависимых пероксидаз, GSH-зависимых изомераз и GSH-зависимых оксидоредуктаз. Вместе они принимают участие в хелатировании тяжелых металлов [7], нейтрализации токсичных ксенобиотиков [8]. Показана связь повышенной экспрессии генов GST в устойчивости к экстремальным температурам [9], засолению [10], гербицидами и заражению мучнистой росой $[11,12]$. Тогда как в арабидопсисе известны 53 различные глутатион-S-трансферазы, а в капусте Brassica oleracea - 65, то в рапсе идентифицировано 179 генов GST, в том числе 141 из них - дуплицицированные [13]. Почти у половины дуплицированных генов характер экспрессии различался. Конкретные фрункции каждого из множества генов GST ни в одном из этих видов растений до сих пор не известны. Изучение конститутивной гетерологичной экспрессии конкретных генов в растениях, созданных методами генной инженерии и геномного редактирования, является одним из лучших способов не только узнать больше о роли этих генов, но и получить ценные сельскохозяйственные растения с повышенной стрессоустойчивостью. Особенный интерес представляет создание растений рапса [14], сверхэкспрессирующих гены GST и оценка изменения реакции таких растений на различные виды стресса.

Работа выполнена при поддержке гранта МК-1146.2020.11 и частично в рамках госзадания (тема № AAAA-A16-116020350028-4). 


\section{Литература}

1. Mikhaylova E. V., Kuluev B. R. Potential for gene flow from genetically modified Brassica napus on the territory of Russia //Environmental monitoring and assessment. 2018. V. 190. No. 9. P. 557. https://doi.org/10.1007/s10661-018-6946-2)

2. Михайлова Е.В., Денисов А.М. Перспективы внедрения в сельскохозяйственное производство биотехнологических сортов рапса // Аграрная Россия. 2017. №7. С. 15-24.

3. Пивень В. Т., Сердюк О. А. Фитосанитарный мониторинг болезней рапса //Масличные культуры. 2011. №. 2. С. 148-149.

4. Гасич Е. Л., Хлопунова Л. Б., Бекиш Л. П. Грибные болезни рапса в СевероЗападном регионе //Земледелие. 2009. №. 2.

5. Артамонов А. А., Горшков В. И. Болезнеустойчивые сорта ярового рапса //Земледелие. 2009. №. 2. С. 45-46

6. Vogel J. P., Raab T. K., Somerville C. R., Somerville S. C. Mutations in PMR5 result in powdery mildew resistance and altered cell wall composition //The Plant Journal. 2004. V. 40. №. 6. P. 968-978.

7. Pilon-Smits E. Phytoremediation //Annu. Rev. Plant Biol. 2005. V. 56. P. 15-39.

8. Marrs K. A. The functions and regulation of glutathione S-transferases in plants //Annual review of plant biology. 1996. V. 47. No. 1. P. 127-158.

9. Kouno T., Ezaki B. Multiple regulation of Arabidopsis AtGST11 gene expression by four transcription factors under abiotic stresses //Physiologia plantarum. 2013. V. 148. No. 1. P. 97-104.

10. Csiszár J. et al. Glutathione transferase supergene family in tomato: salt stressregulated expression of representative genes from distinct GST classes in plants primed with salicylic acid //Plant Physiology and Biochemistry. 2014. V. 78. P. 15-26.

11. Mauch F., Dudler R. Differential induction of distinct glutathione-S-transferases of wheat by xenobiotics and by pathogen attack //Plant Physiology. 1993. V. 102. No. 4. P. 1193-1201.

12. Wang J. M. et al. Analysis of differential transcriptional profiling in wheat infected by Blumeria graminis f. sp. tritici using GeneChip //Molecular biology reports. 2012. V. 39. No. 1. P. 381-387.

13. Wei L. et al. Genome wide identification and comparative analysis of glutathione transferases (GST) family genes in Brassica napus //Scientific reports. 2019. V. 9. No. 1. P. 1-13.

14. Михайлова Е.В., Кулуев Б.Р. Создание трансгенного рапса (Brassica napus L.) с конститутивной экспрессией гена ARGOS-LIKE Arabidopsis thaliana методом погружения цветков // Биотехнология. 2015. №5. С. 49-58. 


\section{The role of glutathione-S-transferases in Brassicaceae plants}

E.V. Mikhaylova, M. Yu. Shein, V.Yu. Alexeev

Institute of biochemistry and genetics UFRC RAS

71 Prospekt Oktyabrya, 450075 Ufa, Republic of Bashkortostan, Russia

Email:mikhele@list.ru

The possibilities to increase stress-tolerance of oilseed rape to powdery mildew and other stress factors by heterologous expression of glutathione-S-transferase genes are discussed.

Keywords: oilseed rape, Brassicaceae, Brassica napus, GST, GSH, powdery mildew, Erysiphe cruciferarum, Erysiphe communis 